\title{
Molecular DFT Investigation on the Inclusion Complexation of Benzo[a]pyrene with $\gamma$-Cyclodextrin
}

\author{
Nadia Mesri, ${ }^{\mathrm{a}, \mathrm{b} @ ~}$ Youghourta Belhocine, ${ }^{\mathrm{c}}$ Nabil Messikh, ${ }^{\mathrm{c}}$ Adlane Sayede, ${ }^{\mathrm{d}}$ \\ and Benali Mouffok ${ }^{a}$ \\ ${ }^{a}$ Laboratoire Synthèse de l'Information Environnementale (LSIE), Faculté des Sciences Exactes, Université Djillali Liabès, \\ 22000 Sidi Bel-Abbès, Algeria. \\ ${ }^{\mathrm{b}}$ Département du TC Sciences et Techniques, Faculté des Sciences et Technologie, Université Mustapha Stambouli, 29000 \\ Mascara, Algeria \\ 'Department of Petrochemical and Process Engineering, Faculty of Technology, 20 August 1955 University of Skikda, 21000 \\ Skikda, Algeria \\ ${ }^{\mathrm{d}}$ UMR 8181 Unité de Catalyse et de Chimie du Solide (UCCS), France \\ ${ }^{\circledR}$ Corresponding authorE-mail:mesri.nadia@univ-mascara.dz,a.mesri.nadia@gmail.com
}

\begin{abstract}
The complexation process between benzo[a]pyrene (BaP) and $\gamma$-cyclodextrin $(\gamma-C D)$ was computationally studied using DFT methodology. Several initial configurations of the interaction of BaP with $\gamma$-CD were explored to determine the most stable inclusion complex. According to the calculated complexation energies, the BaP/ $\gamma$-CD complex is found to be the most favorable energetically when the BaP guest is totally entrapped into $\gamma$-CD cavity. The inclusion process involving the encapsulation of two guests BaP in the cavity of $\gamma$-CD is also thermodynamically favored. Van der Waals interactions play a determinant role in stabilizing $B a P / \gamma-C D$ and $2 B a P / \gamma-C D$ complexes.
\end{abstract}

Keywords: $\gamma$-Cyclodextrin, benzo[a]pyrene, inclusion complex, DFT calculations, Van der Waals interactions.

\section{Молекулярное DFT-исследование комплексообразования включения бензо[а]пирена с $\gamma$-циклодекстрином}

\author{
Н. Месри, ${ }^{\mathrm{a}, \mathrm{b}}$ Ю. Белхосин, ${ }^{\mathrm{c}}$ Н. Мессих, ${ }^{\mathrm{c}}$ А. Сайеде, ${ }^{\mathrm{d}}$ Б. Муфффока \\ ${ }^{\mathrm{a}}$ Факультет точных наук, Университет Джиллали Лябес, 22000 Сиди Бел-Аббес, Алжир \\ ' Факультет науки и технологий, Университет Мустафы Стамбули, 29000 Маскара, Алжир \\ 'Кафедра нефтехимии и технологического проектирования технологического факультета, 20 августа 1955 г. \\ Университет Скикды, 21000 Скикда, Алжир \\ ¿Oтдел твердотельного катализа и химии UMR 8181 (UCCS), Франциия \\ ${ }^{\circledR}$ E-mail: mesri.nadia@univ-mascara.dz,a.mesri.nadia@gmail.com
}

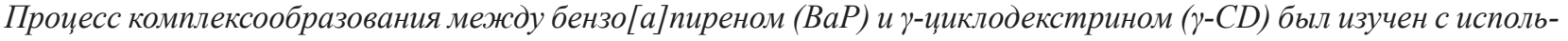
зованием DFT расчетов. Было исследовано несколько начальных конфигураций взаимодействия ВаР с $\gamma$-CD, чтобы определить наиболее стабильный комплекс включения. Согласно рассчитанным энергиям комплексоо-

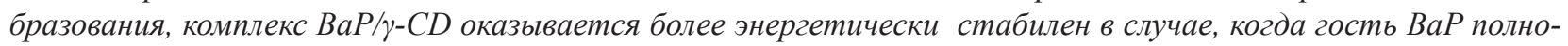
стью захвачен в полость ү-CD. Процесс включения, в который вовлечена инкапсуляция двух гостей ВаР в полость $\gamma$-CD, также термодинамически благоприятен. Ван-дер-Ваальсовы взаимодействия играют определяющую роль в стабилизации комплексов $B a P / \gamma-C D$ и $2 B a P / \gamma-C D$.
\end{abstract}

Ключевые слова: $\gamma$-Циклодекстрин, бензо[а]пирен, комплекс включения, DFT расчеты, Ван-дер-Ваальсовы взаимодействия. 


\section{Introduction}

Benzo[a]pyrene ( $\mathrm{BaP}$ ) belongs to the class of polycyclic aromatic hydrocarbons (PAHs), which are formed during the incomplete combustion of organic matter. ${ }^{[1,2]}$ They are ubiquitous pollutants of major concern because of their significant toxicity to humans, ${ }^{[3-5]}$ ecotoxicity, carcinogenicity, mutagenicity and effects on reproductive ability. ${ }^{[6-9]}$

Benzo[a]pyrene is a byproduct of incomplete combustion or pyrolysis of organic materials; $;^{[6,10]}$ it was characterized and identified at the beginning of the 1930s when Cook, Hewett and Heiger succeeded to synthesize it. ${ }^{[1]}$ The crystalline form of $\mathrm{BaP}$ was originally reported by John Iball in $1936,{ }^{[12]}$ and already at that time its acute toxicity and high carcinogenicity were well known. In the human body, BaP is metabolized to highly reactive species (diol epoxide, quinone or radical cations) which damage DNA leading to cancer; it is the most active carcinogen. ${ }^{[13,14]}$ Major routes of exposure are via inhalation and food intake. Chronic BaP exposure has been associated with the development of various human cancers, including lung, breast and liver cancer; it is classified in Group 1 (carcinogenic to humans) by the International Agency for Research on Cancer (IARC). ${ }^{[15]}$

Benzo[a]pyrene is also considered as the prototypical $\mathrm{PAH}$, an indicator for PAH contamination with the highest toxicity equivalent factor (TEF) that made it a reference in the toxicity ${ }^{[16]}$ (Scheme 1). The toxic equivalency factor (TEF) makes it possible to evaluate the toxicity of PAHs that have poor toxicological data on the carcinogenicity with quantitative estimates of their carcinogenic potency expressed relative to that of $\mathrm{BaP}$, this allows to analyze their presence in food webs and to attribute a biological significance to their concentrations measured in tissues; ${ }^{[17,18]}$ the presence of benzo[a]pyrene has been identified in a wide range of environmental and combustion-related samples such as cigarette smoke, sediment, air particulate, water, coal tar, crude oil, and diesel particulate, ${ }^{[19,20]}$ and tend to persist in the environment partly and accumulate in soils due to its high hydrophobicity and its strong adsorption onto the soil organic matter, these properties make biodegradation or chemical treatments of BaP very difficult. ${ }^{[21,22]}$

Among the methodologies developed to extract, treat or analyze $\mathrm{BaP}$ and other PAHs are the use of cyclodextrins $(\mathrm{CDs}){ }^{[23,24]}$ that are cyclic oligomers composed of six, seven or eight glucopyranose units which are commonly available in three types $\alpha$ - (alpha), $\beta$ - (beta) and $\gamma$ - (gamma) and presenting enclosed cavities approximately of 4.7-5.3, 6.0-6.5, and $7.5-8.3 \AA$ in diameter, respectively. The external part of the cyclodextrins is hydrophilic whereas the interior cavity is hydrophobic enabling them to entrap guest molecules in their molecular cavities, thus allowing remarkable effects in stabilizing and solubilizing lipophilic unstable substances without the formation of chemical bonds and without changing their structure; such physical interaction can be considered as an encapsulation of substances at a molecular scale via non-covalent interactions. ${ }^{[25]}$

These inclusion systems by encapsulation have allowed cyclodextrins to be widely used in various fields such as pharmaceuticals (vectorization of active ingredients), food technology and cosmetics (aroma protection against oxidation, light and heat, controlled release of fragrances), agriculture (encapsulation of insecticides), chemical analysis (separation method, chromatography, etc.), catalysis (biphasic catalysis), textiles and environmental sciences (water treatment, cleaning of polluted soils, air analysis, etc.). ${ }^{[26-29]}$

The inclusion of $\mathrm{BaP}$ by cyclodextrin hosts and their derivatives has been subject to some studies in the literature $^{[30-34]}$ that were dedicated to the improvement of $\mathrm{BaP}$ biodegradation, however, most of these studies focused on the use of $\beta$-cyclodextrin ( $\beta$-CD) or its derivatives as a host due to its availability, price and cavity size suitable for a broad range of guest molecules.

In this context, the experimental work of Patonay et $a l^{[33]}$ regarding the possible formation of inclusion complexes between $\mathrm{BaP}$ and $\alpha$-, $\beta$-, and $\gamma$-cyclodextrin showed that the formation constant is larger for $\mathrm{BaP} / \gamma-\mathrm{CD}$ than for $\mathrm{BaP} / \alpha-\mathrm{CD}$ and $\mathrm{BaP} / \beta-\mathrm{CD}$ complexes. It is also found that $\mathrm{BaP}$ forms 1:1 inclusion complex with $\gamma-\mathrm{CD}$, however, it is less likely for $\gamma$-CD to accommodate two guest $\mathrm{BaP}$ molecules inside its cavity, however, the spectroscopic binding studies carried out by woodberry et al. ${ }^{[34]}$ suggested the possible formation of 2:1 guest:host inclusion complex of $\mathrm{BaP}$ metabolites in $\gamma$-CD.

In the present investigation, the inclusion complex process between $\mathrm{BaP}$ and $\gamma-\mathrm{CD}$ was explored by employing density functional theory (DFT) calculations.

\section{Computational Methods}

The starting molecular structure of $\gamma-\mathrm{CD}$ was taken from the crystal structure of uncomplexed $\gamma$-cyclodextrin determined by X-ray diffraction. ${ }^{[35]}$ The BaP molecule was drawn with Avogadro (version 1.2.0) software. ${ }^{[36]}$ Both structures of $\gamma-\mathrm{CD}$ and $\mathrm{BaP}$ were subjected to geometry optimization at DFT/B97-D3BJ/def2svp level of theory with ORCA program. ${ }^{[37,38]}$ Frequency calculations were performed to characterize the structures as minimum points on the potential energy surface. The optimized structures were then used to build the inclusion models. The process of inclusion is represented in Figure 1, where the center of $\gamma$-CD cavity was defined as the center of the whole system $(\mathrm{z}=0 \AA)$ and the $\mathrm{BaP}$ guest passes through the cavity of $\gamma-\mathrm{CD}$ from $-8 \AA$ to $+8 \AA$ along the $z$-axis with a step of $1 \AA$. The minimum-energy configurations were identified according to the method of Liu et al. ${ }^{[39]}$ For each step, the geometry of the complex was fully optimized using ORCA program in water solvent with the CPCM model ${ }^{[40]}$ at B97-D3BJ/def2-svp level of theory ${ }^{[41-44]}$ without assuming any symmetry constraints; a geometrical counterpoise correction ${ }^{[45]}$ (gCP) for basis set superposition error (BSSE) in the def2-SVP basis was applied, as well as the resolution of identity approxima$\operatorname{tion}^{[46,47]}(\mathrm{RI})$ and fine integration grids (Grid5 for SCF iterations and Grid6 for the final energy). All the calculations were carried out on Intel Core $158600 \mathrm{~K}$ processor personal computer having 16 GB memory, the average calculation time of full geometry optimization for each configuration was about 2.5 days.

The complexation energies $(\Delta E)$ were computed by the equation (1) in order to evaluate energetically the inclusion process between $\mathrm{BaP}$ and $\gamma$-CD in their final optimized geometries:

$$
\Delta E=E_{\text {complex }}-\left(E_{\mathrm{BaP}}+E_{\gamma-\mathrm{CD}}\right),
$$

where $E_{\text {complex }}, E_{\mathrm{BaP}}$ and $E_{\gamma-\mathrm{CD}}$ are respectively the total energy of the complex, the free optimized $\mathrm{BaP}$ and the free optimized $\gamma-\mathrm{CD}$.

The most stable structure among the calculated ones corresponds to the conformation with the lowest total energy value for both A and B models. 


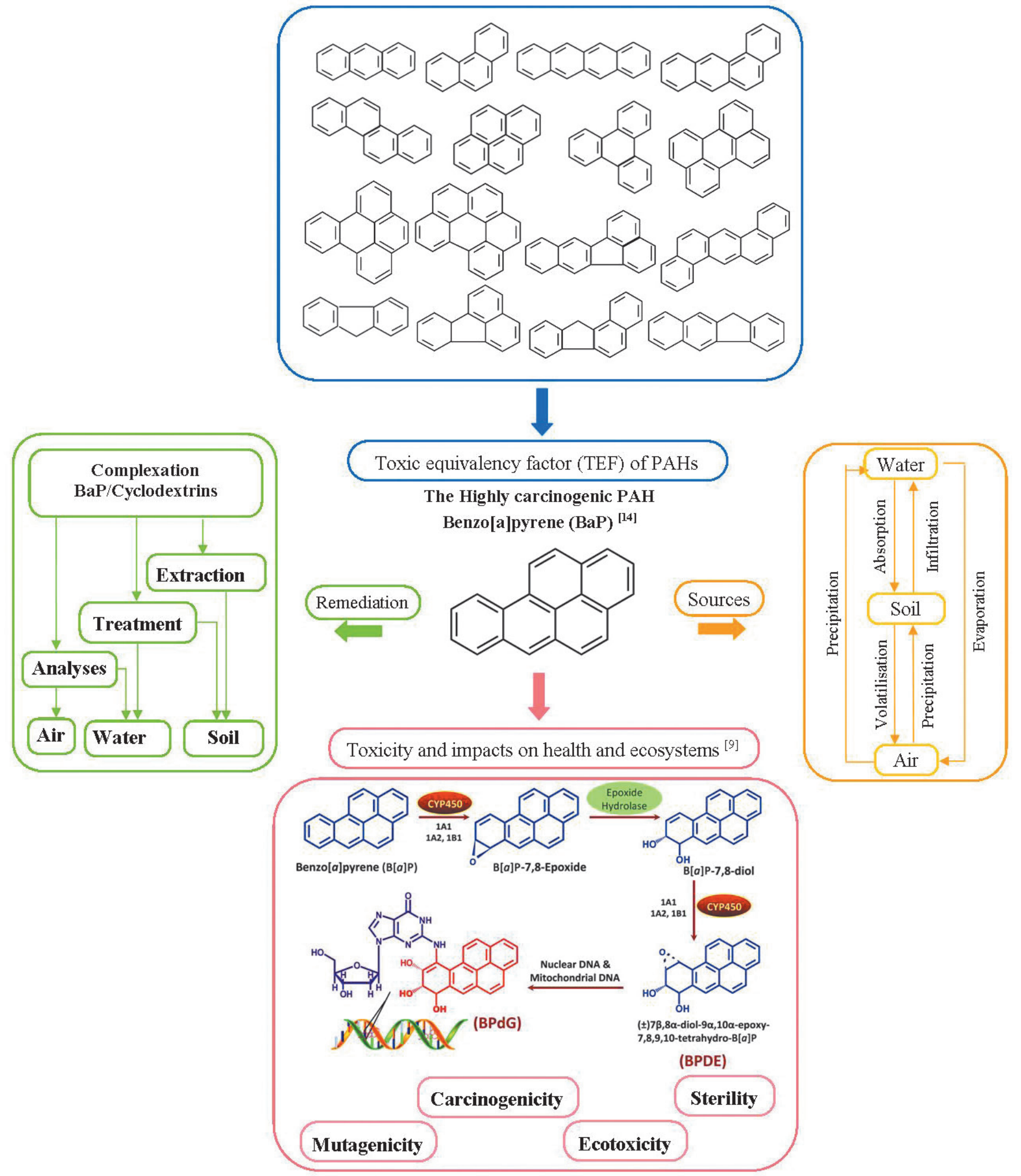

Scheme 1. Toxic and health effects of benzo[a]pyrene on organisms and environment.

\section{Results and Discussion}

\section{Complexation Energy Computations}

The computed complexation energies of the most stable conformations corresponding to the minimum-energy structures found for A and B models are reported in Table 1.
The complexation energy values are negative, implying a favorable thermodynamic process, and they are found to be more negative when the $\mathrm{BaP}$ penetrates the $\gamma-\mathrm{CD}$ cavity more deeply. Indeed, the energy of the complexation increases negatively as the $\mathrm{BaP}$ guest approaches the center of $\gamma$-CD cavity, suggesting that weak intermolecular forces are behind the stability of the formed complexes. ${ }^{[49-51]}$ 


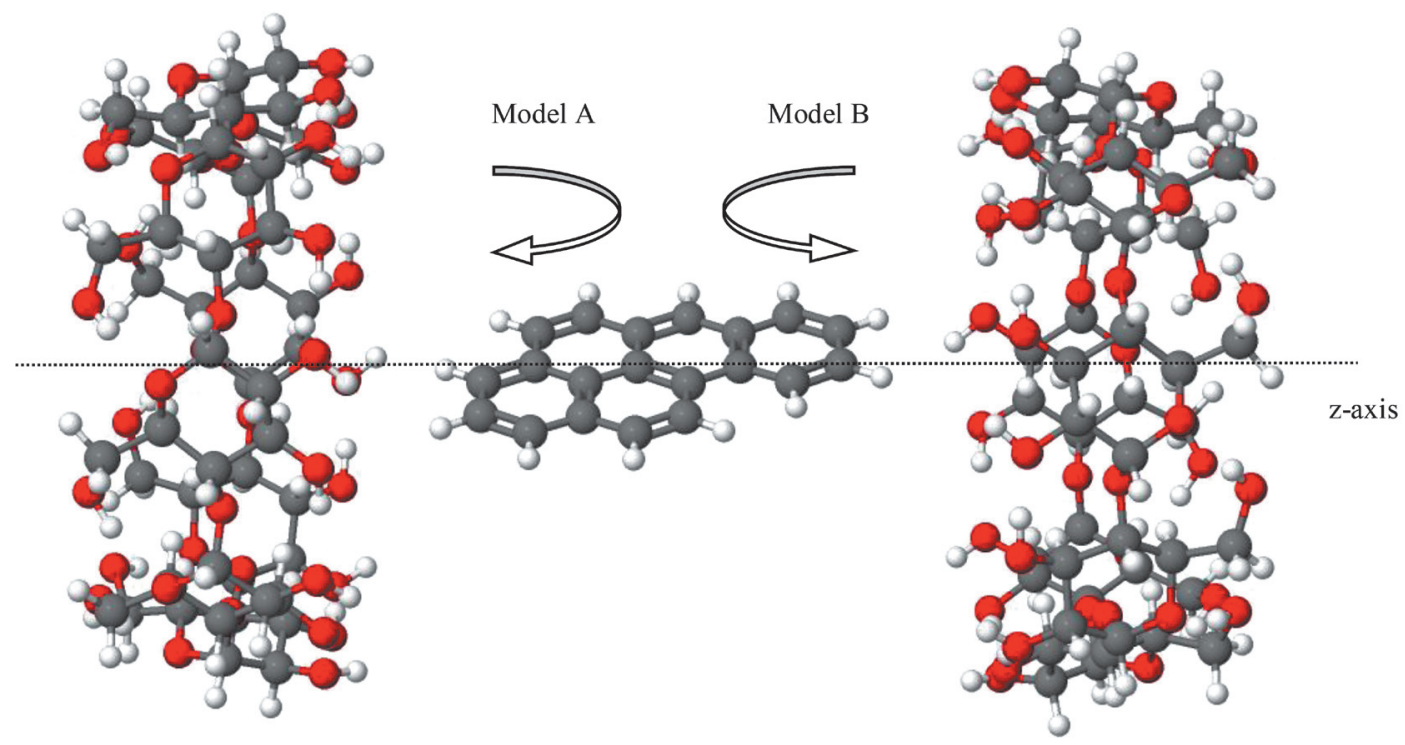

Figure 1. Illustration of the inclusion models of $\mathrm{BaP}$ in $\gamma$-CD visualized by Jmol viewer applet. ${ }^{[48]}$ Color code of atoms (grey for $\mathrm{C}$, red for $\mathrm{O}$ and white for $\mathrm{H}$ ).

The most stable conformations for both A and B models are located at $\mathrm{z}=0 \AA$ (Table 1), the corresponding complexation energies are respectively -61.71 and $-48.13 \mathrm{~kJ} / \mathrm{mol}$, with an energy difference of $13.58 \mathrm{~kJ} / \mathrm{mol}$ in favor of A model.

Table 1. Computed complexation energies $(\mathrm{kJ} / \mathrm{mol})$ of $\mathrm{BaP} / \gamma-\mathrm{CD}$ at B97-D3BJ/def2-SVP level in CPCM water model

\begin{tabular}{|c|c|c|c|}
\hline $\begin{array}{c}\text { Initial } \\
\text { configurations }(\AA)\end{array}$ & $\begin{array}{c}\mathrm{BaP} / \gamma-\mathrm{CD} \\
(\mathrm{kJ} / \mathrm{mol})\end{array}$ & $\begin{array}{c}\text { Initial } \\
\text { configurations }(\AA)\end{array}$ & $\begin{array}{c}\mathrm{BaP} / \gamma-\mathrm{CD} \\
(\mathrm{kJ} / \mathrm{mol})\end{array}$ \\
\hline Model A & & Model B & \\
\hline-8 & -13.60 & -8 & -29.10 \\
\hline-7 & -21.00 & -7 & -3.42 \\
\hline-6 & -24.75 & -6 & -26.39 \\
\hline-5 & -27.99 & -5 & -31.61 \\
\hline-4 & -32.72 & -4 & -35.09 \\
\hline-3 & -39.44 & -3 & -37.14 \\
\hline-2 & -43.34 & -2 & -43.35 \\
\hline-1 & -47.03 & -1 & -36.39 \\
\hline 0 & -61.71 & 0 & -48.13 \\
\hline+1 & -46.13 & +1 & -42.73 \\
\hline+2 & -45.79 & +2 & -42.78 \\
\hline+3 & -41.20 & +3 & -40.49 \\
\hline+4 & -39.91 & +4 & -41.58 \\
\hline+5 & -28.67 & +5 & -25.45 \\
\hline+6 & -28.16 & +6 & -18.53 \\
\hline+7 & -8.89 & +7 & -15.73 \\
\hline+8 & -2.17 & +8 & -11.16 \\
\hline
\end{tabular}

\section{Electronic and Sensing Properties} of $\gamma$-CD towards $B a P$

The calculated quantum chemical parameters ${ }^{[52-54]}$ such as frontier molecular orbitals (HOMO and LUMO), HOMOLUMO energy gap, dipole moment $(\mu)^{[55]}$ and the percentage of variation of HOMO-LUMO gap $\left|\Delta E_{\mathrm{g}}\right|^{[56,57]}$ can be useful for rationalizing the electronic properties of both $\gamma-C D$ and the formed inclusion complex $\mathrm{BaP} / \gamma-\mathrm{CD}$. The computed values for these quantities are listed in Table 2.

Table 2. Computed chemical parameters of $\gamma-\mathrm{CD}$ and $\mathrm{BaP} / \gamma-\mathrm{CD}$ complex.

\begin{tabular}{lcc}
\hline \multicolumn{1}{c}{ Chemical Parameters } & $\gamma$-CD & $\mathrm{BaP} / \gamma-\mathrm{CD}$ \\
\hline Dipole moment $\mu(\mathrm{D})$ & 14.00 & 14.05 \\
HOMO $(\mathrm{eV})$ & -5.89 & -4.75 \\
LUMO $(\mathrm{eV})$ & 0.39 & -2.57 \\
Gap $E_{\mathrm{g}}(\mathrm{eV})$ & 6.28 & 2.18 \\
Gap variation $\left|\Delta E_{\mathrm{g}}\right|(\%)$ & - & 65.29 \\
\hline
\end{tabular}

The results reported in Table 2 show that the HOMO and LUMO levels are shifted to upper and lower energies, respectively upon the formation of the inclusion complex $\mathrm{BaP} / \gamma-\mathrm{CD}$, leading to a significant decrease of the HOMO-LUMO energy gap from $6.28 \mathrm{eV}$ for $\gamma$-CD to $2.18 \mathrm{eV}$ for the complex $\mathrm{BaP} / \gamma-\mathrm{CD}$. The percentage variation in HOMO-LUMO gap $\left|\Delta E_{\mathrm{g}}\right|$ is about $65.3 \%$. Thus, the electrical properties of $\mathrm{BaP} / \gamma-\mathrm{CD}$ complex are significantly affected by the complexation process; therefore, $\gamma-\mathrm{CD}$ can be used as a sensor for electrical detection of BaP. Once the complex is formed, a negligible variation in the global dipole moment is observed (14.00 D for $\gamma$-CD and 14.05 D for $\mathrm{BaP} / \gamma-\mathrm{CD})$, suggesting that electric dipole moment does not appear to influence the complexation process. 

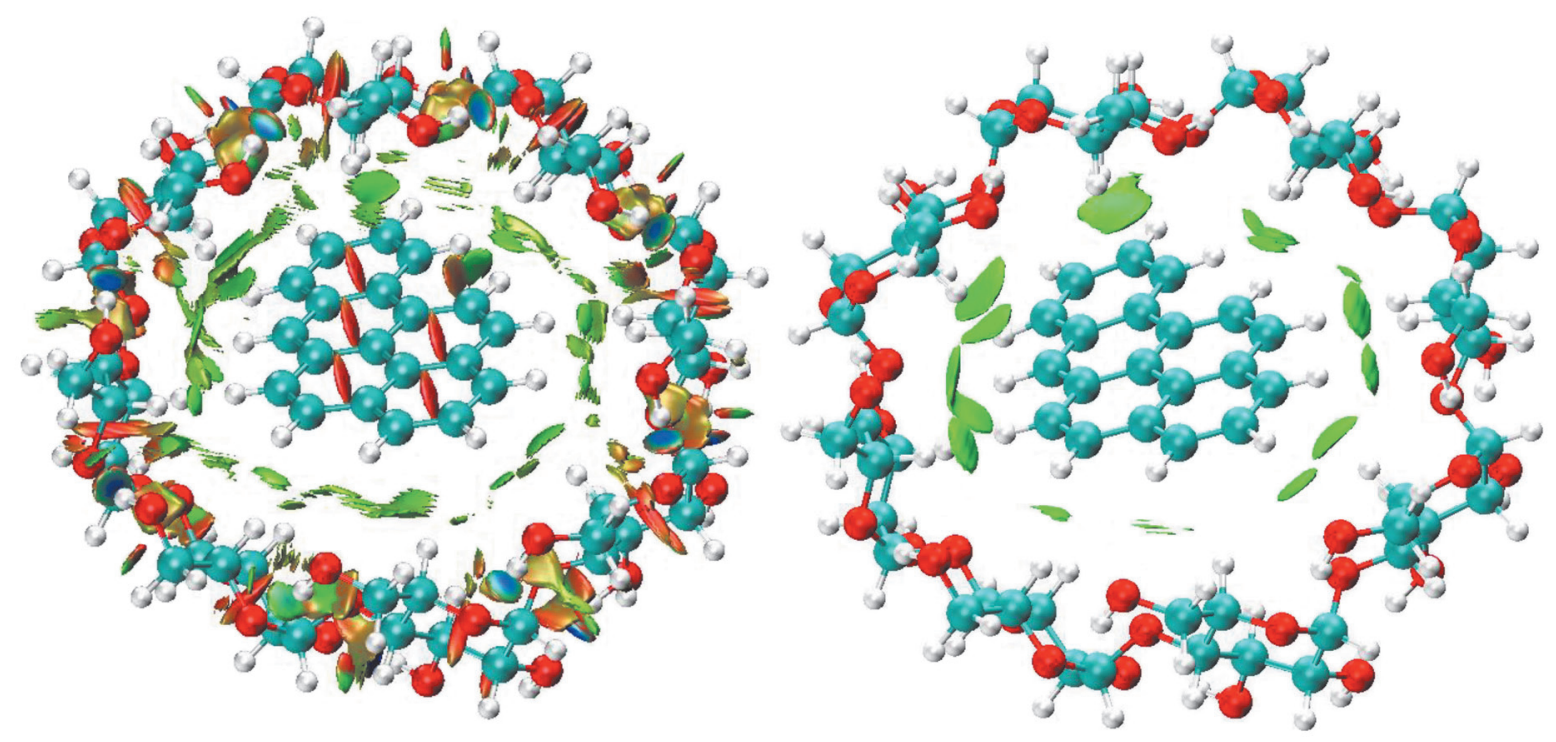

Figure 2. RDG (left isovalue 0.7 a.u.) and IGM (right isovalue 0.003 a.u.) isosurfaces of $\mathrm{BaP} / \gamma$-CD complex.

\section{Non-covalent Interaction Analysis}

In order to gain a better understanding of the driving forces that govern the complexation of BaP with $\gamma-\mathrm{CD}$, a non-covalent interaction (NCI) analysis ${ }^{[58]}$ through the reduced density gradient (RDG) ${ }^{[59]}$ and independent gradient model based on Hirshfeld partition of molecular density $(\mathrm{IGMH})^{[60]}$ was performed by Multiwfn program. ${ }^{[61]}$ VMD software ${ }^{[62]}$ was used for three-dimensional visualization of RDG and IGM isosurfaces of $\mathrm{BaP} / \gamma-\mathrm{CD}$ complex that are illustrated in Figure 2. The isosurfaces are colored depending on the type of the interaction, thus green, red and blue colors are assigned respectively to weak Van der Waals interactions, steric repulsion and strong electrostatic interactions.

The analysis of intramolecular interactions through the RDG isosurface in Figure 2 (left) revealed the presence of intramolecular hydrogen bonding (blue color) and steric repulsion (red color) occurring in $\gamma$-CD whereas steric repulsion (red rice grain-shaped) is dominant within the aromatic rings of BaP. The IGM isosurface (Figure 2 right) identified the intermolecular interactions between $\gamma-\mathrm{CD}$ and $\mathrm{BaP}$ and showed that Van der Waals interactions (green color) are solely involved in the formation of the $\mathrm{BaP} / \gamma-\mathrm{CD}$ complex.

\section{Formation of 1:2 Host-Guest Inclusion Complex of $\gamma-C D$ with $B a P$}

To determine theoretically if an inclusion complex can also be formed between $\gamma$-CD and two guest $\mathrm{BaP}$ molecules, DFT calculations were performed with the same level of theory used for 1:1 host-guest inclusion complex. The calculated complexation energy for $2 \mathrm{BaP} / \gamma-\mathrm{CD}(-165.17 \mathrm{~kJ} / \mathrm{mol})$ indicates the higher probability of formation of an inclusion complex involving the encapsulation of two $\mathrm{BaP}$ molecules in the cavity of $\gamma-\mathrm{CD}$. The non-covalent intra- and intermolecular interactions through RDG isosurface are illustrated in Figure 3. It was found that the inclusion process of two
$\mathrm{BaP}$ molecules in $\gamma$-CD is largely governed by weak van der Waals interactions indicated by the green or green-brown colors in the RDG isosurface. The BaP guests (dimer) are arranged in a parallel-displaced geometry, contributing, therefore, to energy stabilization of the formed complex. Indeed, the combined effects of $\pi \cdots \pi$ stacking as a result of the attraction between the $\pi$ clouds of the aromatic rings lead to a significant increase in interaction energy between the BaP dimer $(-66.97 \mathrm{~kJ} / \mathrm{mol})$. Our calculations showed also that the theoretical volume of the $\gamma$-CD cavity increased by $15.7 \%$ once the two $\mathrm{BaP}$ guests are encapsulated, therefore, due to the conformational flexibility of its structure, $\gamma$-CD can accommodate two $\mathrm{BaP}$ as guests. The electrical properties of $2 \mathrm{BaP} / \gamma-\mathrm{CD}$ complex are more affected if compared with $\gamma-\mathrm{CD}$ and $\mathrm{BaP} / \gamma-\mathrm{CD}$ complex, the HOMO and the LUMO are respectively the highest $(-4.26 \mathrm{eV})$

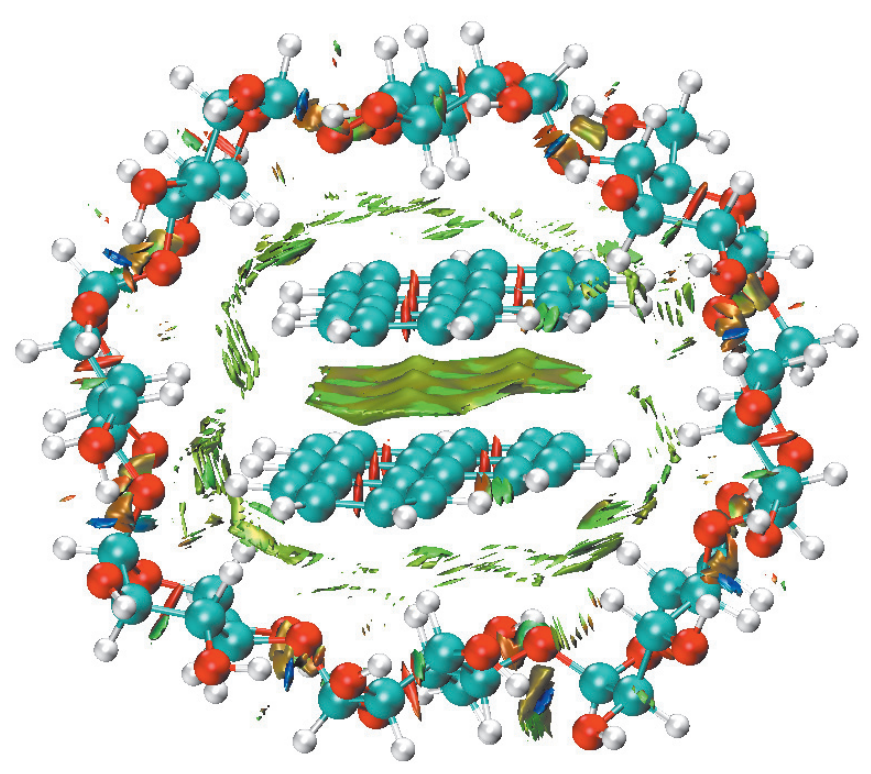

Figure 3. RDG isosurface (isovalue 0.5 a.u.) of intra- and intermolecular non-covalent interactions in $2 \mathrm{BaP} / \gamma$-CD complex. 
and the lowest $(-2.31 \mathrm{eV})$ in energy and hence the gap is even lower $(1.95 \mathrm{eV})$. The percentage variation in HOMO-LUMO gap $\left|\Delta E_{\mathrm{g}}\right|$ for $2 \mathrm{BaP} / \gamma-\mathrm{CD}$ complex is about $69 \%$ denoting, therefore, more sensing properties when two BaP molecules are entrapped.

\section{Conclusions}

The formation of 1:1 and 1:2 host-guest inclusion complexes of $\gamma$-cyclodextrin with benzo[a]pyrene was theoretically investigated by means of DFT calculations. Both 1:1 and 1:2 host-guest complexes are energetically favored due to their negative complexation energies. Van der Waals forces stabilize and govern the intermolecular interactions occurring within $\mathrm{BaP} / \gamma-\mathrm{CD}$ and $2 \mathrm{BaP} / \gamma-\mathrm{CD}$ complexes. The electrical properties based on the percentage variation of the HOMO-LUMO gap showed that $\gamma$-cyclodextrin can serve as a sensor for detecting the presence of benzo[a] pyrene. Our results indicate also the good conformational flexibility of $\gamma$-cyclodextrin which allows an increase of its cavity volume by $15.7 \%$ to ensure the inclusion of two benzo[a]pyrene guests.

\section{References}

1. Katsoyiannis A., Breivik K. Environ. Pollut. 2014, 184, 488-494. doi:10.1016/j.envpol.2013.09.028.

2. Zhou H., Wu C., Onwudili J.A., Meng A., Zhang Y., Williams P.T. Waste Manage. 2015, 36, 136-146. doi:10.1016/j.wasman.2014.09.014.

3. Rengarajan T., Rajendran P., Nandakumar N., Lokeshkumar B., Rajendran P., Nishigaki I. Asian Pac. J. Trop. Biomed. 2015, 5, 182-189. doi:10.1016/s2221-1691(15)30003-4.

4. Wang, L., Zhang, S., Wang, L., Zhang, W., Shi, X., Lu, X., Li, X. Int. J. Environ. Res. Public Health. 2018, 15, 607. doi:10.3390/ijerph15040607.

5. Chang Y., Siddens L.K., Heine L.K., Sampson D.A., Yu Z., Fischer K.A., Löhr C.V., Tilton S.C. Toxicol. Appl. Pharmacol. 2019, 379, 114644. doi:10.1016/j.taap.2019.114644.

6. Chang Y., Huynh C.T.T., Bastin K.M., Rivera B.N., Siddens L.K., Tilton S.C. Toxicol. In Vitro 2020, 104991. doi:10.1016/j. tiv.2020.104991.

7. Bolden A.L., Rochester J.R., Schultz K., Kwiatkowski C.F. Reprod. Toxicol. 2017, 73, 61-74. doi:10.1016/j.reprotox.2017.07.012.

8. Cathey A.L., Watkins D.J., Rosario Z.Y., Vélez Vega C.M., Loch-Caruso R., Alshawabkeh, A.N., Cordero J.F., Meeker J.D. Sci. Total Environ. 2020, 141581. doi:10.1016/j.scitotenv.2020.141581.

9. Barnes J.L., Zubair M., John K., Poirier M.C., Martin F.L. Biochem. Soc. Trans. 2018, 46,1213-1224. doi:10.1042/ bst20180519.

10. De la Rosa J.M., Sánchez-Martín A.M., Campos P., Miller A.Z. Sci. Total Environ.. 2019, 667, 578-585. doi:10.1016/j. scitotenv.2019.02.421.

11. Cook J.W., Hewett C.L., Hieger I. J. Chem. Soc. 1933, 106, 395. doi:10.1039/jr9330000395.

12. Phillips D.H. Nature 1983, 303(5917), 468-472. doi:10.1038/303468a0.

13. Nebert D.W., Shi Z., Galvez-Peralta M., Uno S., Dragin N. Mol. Pharmacol. 2013, 84, 304-313. doi:10.1124/mol.113.086637.

14. Honda M., Suzuki N. Int. J. Environ. Res. Public Health 2020 , 17, 1363. doi:10.3390/ijerph17041363.
15. IARC. IARC. Monogr. Eval. Carcinog. Risks Hum. 2012, $100 F, 111-144$.

16. Nisbet I.C.T., LaGoy P.K. Regul. Toxicol. Pharmacol. 1992, 16, 290-300. doi:10.1016/0273-2300(92)90009-x.

17. Petry T., Schmid P., Schlatter C. Chemosphere 1996, 32, 639-648. doi:10.1016/0045-6535(95)00348-7.

18. Ohiozebau E., Tendler B., Codling G., Kelly E., Giesy J.P., Jones P.D. Environ. Geochem. Health. 2016, 39, 139-160. doi:10.1007/s10653-016-9815-3.

19. Song Y., Nahrgang J., Tollefsen K.E. Sci. Total Environ. 2019, 653, 176-189. doi:10.1016/j.scitotenv.2018.10.261.

20. Boente C., Baragaño D., Gallego J. R. Environ. Pollut. 2020, 266, 115341. doi:10.1016/j.envpol.2020.115341.

21. Choong C.E., Wong K.T., Yoon S.Y., Kim, H., Shin, M., Chang Y.Y., Yang J.K., Kim S.H., Jeon B.H., Yoon Y., Jang M. J. Clean. Prod. 2021, 278, 123425. doi:10.1016/j. jclepro.2020.123425.

22. Morales P., Cáceres M., Scott F., Díaz-Robles L., Aroca G., Vergara-Fernández A. Appl. Microbiol. Biotechnol. 2017, 101, 6765-6777. doi:10.1007/s00253-017-8400-8.

23. Veignie E., Rafin C., Landy D., Fourmentin S., Surpateanu G. J. Hazard. Mater. 2009, 168, 1296-1301. doi:10.1016/j. jhazmat.2009.03.012.

24. Greene L., Elzey B., Franklin M., Fakayode S.O. Spectrochim. Acta 2017, 174, 316-325. doi:10.1016/j.saa.2016.11.047.

25. Szejtli, J. Chem. Rev. 1998, 98, 1743-1753. doi:10.1021/ cr970022c.

26. Tian B., Xiao D., Hei T., Rui Ping R., Shiyao Huac S., Liuc J. Polym Int. 2020, 69, 597-603. doi:10.1002/pi.5992.

27. Carneiro S., Costa Duarte F., Heimfarth L., Siqueira Quintans J., Quintans-Júnior L., Veiga Júnior V., Neves de Lima Á. Int. J. Mol. Sci. 2019, 20, 642. doi:10.3390/ijms20030642.

28. Sayede A., Ponchel A., Filardo G., Galia A., Monflier E. J. Mol. Struct. 2006, 777, 99-106. doi:10.1016/j.theochem.2006.08.033.

29. Bednarek E., Bociana W., Michalska K. J. Pharm. Biomed. Anal. 2019, 169, 170-180. doi:10.1016/j.jpba.2019.02.031.

30. Westerberg G., Wiklund L. J. Pharm. Sci. 2005, 94, 114-119. doi:10.1002/jps.20198.

31. Liu T., Ding K., Guo G., Yang F., Wang L. Chem Ecol. 2018, 34, 519-531. doi:10.1080/02757540.2018.1462343.

32. Yang M., Wang Y., Wang H. Electrochim. Acta 2015, 169, 7-12. doi:10.1016/j.electacta.2015.04.057.

33. Patonay G., Warner I.M. J. Incl. Phenom. Macrocycl. Chem. 1991, 11, 313-322. doi:10.1007/bf01041410.

34. Woodberry R., Ransom S., Chen F.M. Anal. Chem. 1988, 60, 2621-2625. doi:10.1021/ac00174a017.

35. Harata K. Bull. Chem. Soc. Jpn. 1987, 60, 2763-2767. doi:10.1246/bcsj.60.2763.

36. Hanwell M.D., Curtis D.E., Lonie D.C., Vandermeersch T., Zurek E., Hutchison G.R. J. Cheminform. 2012, 4, 17. doi:10.1186/1758-2946-4-17.

37. Neese F., The ORCA program system, Wiley Interdiscip. Rev.: Comput. Mol. Sci. 2012, 2, 73-78. doi:10.1002/wcms.81.

38. Neese F., Software update: the ORCA program system, version 4.0. WIREs Comput. Mol. Sci. 2017, 8, e1327. doi:10.1002/ wcms.1327.

39. Liu L., Guo Q.X. J. Incl. Phenom. Macrocycl. Chem. 2004, 50, 95-103. doi:10.1007/s10847-003-8847-3.

40. Takano Y., Houg K.N. J. Chem. Theory Comput. 2005, 1, 70-77. doi:10.1021/ct049977a.

41. Becke A.D. J. Chem. Phys. 1997, 107, 8554. doi:10.1063/1.475007.

42. Grimme S., Ehrlich S., Goerigk L. J. Comput. Chem. 2011, 32, 1456-1465. doi:10.1002/jcc.21759.

43. Grimme S., Antony J., Ehrlich S., Krieg H. J. Chem. Phys. 2010, 132, 154104. doi:10.1063/1.3382344. 
DFT Investigation on the Inclusion Complexation of Benzo[a]pyrene with $\gamma$-Cyclodextrin

44. Weigend F., Ahlrichs R. Phys. Chem. Chem. Phys. 2005, 7, 3297. doi:10.1039/b508541a.

45. Kruse H., Grimme S. J. Chem. Phys. 2012, 136, 154101. doi:10.1063/1.3700154.

46. Weigend F. Phys. Chem. Chem. Phys. 2006, 8, 1057-1065. doi:10.1039/b515623h.

47. Eichkorn K., Treutler O., Öhm H., Häser M., Ahlrichs R. Chem. Phys. Lett., 1995, 242, 652-660. doi: 10.1016/00092614(95)00838-U.

48. Jmol: an open-source Java viewer for chemical structures in 3D. http://www.jmol.org/ Accessed date: July 23, 2021.

49. Assaba I.M., Rahali S., Belhocine Y., Allal H. J. Mol. Struct. 2021, 1227, 129696. doi:10.1016/j.molstruc.2020.129696.

50. Belhocine Y., Bouhadiba A., Rahim M., Nouar L., Djilani I., Khatmi D-E. Macroheterocycles 2018, 11, 203-209. doi:10.6060/mhc170829b.

51. de Sousa F.B., Leite Denadai A.M., Lula I.S., Nascimento Jr C.S., Fernandes Neto N.S.G., Lima A.C., de Almeida W.B., Sinisterra R.D. J. Am. Chem. Soc. 2008, 130, 8426-8436. doi:10.1021/ja801080v.

52. Venkatesh G., Sivasankar T., Karthick M. Rajendiran N. J. Incl. Phenom. Macrocycl. Chem. 2013, 77, 309-318. doi:10.1007/s10847-012-0248-z.
53. Ammouchi N., Allal H., Belhocine Y., Bettaz S., Zouaoui E. J. Mol. Liq. 2020, 300, 133-145. doi:10.1016/j.molliq.2019.112309.

54. Elistratova M.A., Zakharova I.B., Kvyatkovskii O.E. Macroheterocycles 2019, 12, 370-374. doi:10.6060/mhc190552e.

55. Fifere A., Marangoci N., Maier S., Coroaba A., Maftei D., Pinteala M. Beilstein J. Org. Chem. 2012, 8, 2191-2201. doi:10.3762/bjoc.8.247.

56. Nagarajan V., Chandiramouli R. Appl. Surf. Sci. 2015, 344, 65-78. doi:10.1016/j.apsusc.2015.03.069.

57. Allal H., Belhocine Y., Rahali S., Damous M., Ammouchi N. J. Mol. Model. 2020, 26, 128. doi:10.1007/s00894-020-04388-3.

58. Contreras-García J., Boto R.A., Izquierdo-Ruiz F., Reva I., Woller T., Alonso M. Theor. Chem. Acc. 2016, 135, 242. doi:10.1007/s00214-016-1977-7.

59. Saleh G., Gatti C., Presti L.L. Comput. Theor. Chem. 2012 998, 148-163. doi:10.1016/j.comptc.2012.07.014.

60. Lefebvre C., Rubez G., Khartabil H., Boisson J.C., ContrerasGarcía J., Hénon E. Phys. Chem. Chem. Phys. 2017, 19, 17928-17936. doi:10.1039/c7cp02110k.

61. Lu T., Chen F. J. Comput. Chem. 2012, 33, 580-592. doi:10.1002/jcc. 22885 .

62. Humphrey W., Dalke A., Schulten K. J. Mol. Graph. 1996, 14, 33-38. doi:10.1016/0263-7855(96)00018-5. 